\title{
Essentialism In and About Development Discourse
}

\author{
DES GASPER
}

Several types of essentialism form potential dangers in policy and development discourse. First, essentialism in defining terms, including in claims that a term referring to a broad and multi-dimensional category means 'essentially' and exclusively such-and-such and is not 'essentially contestable'. Second, essentialism about the performance and desirability of policies and policy means, including: the treatment of a means or strategy as having 'inherent' performance attributes (strengths/weaknesses); and the treatment of a means as inherently (or 'basically') appropriate and 'proper'. Illustrations come from debates on rural centres, co-operatives, and collectivisation. Thirdly, essentialism in descriptions of schools of development thought and practice, discussed with reference to work by Kitching, Ferguson, Escobar and others on development discourse, and the stream of 'antidevelopment discourse'.

\section{THE BASIC DEFECTS OF YOUR ESSENTIAL VISION OF}

DEVELOPMENT AND THE INHERENT STRENGTHS OF MY FAVOURED POLICY MEANS

Various authors propose lists of basic features of development discourse or of some mainstream in it. One central proposed feature is a frequent usage of the term 'development' as simultaneously descriptive and evaluative: as referring to specific empirical features or processes and at the same time as inherently good, good by definition. James Ferguson, like some earlier authors, describes this as a tacit oscillation between two definitions of development, one meaning modernisation, industrialisation and/or transition to capitalism, and the other meaning improvement of quality of life or increase of well-being [1990: 15, 55]. Negative experiences of industrialisation or capitalism or whatever then become excused as not real examples, not 'real development'; and the concept of 'development' can live on as at the same time a definite programme and an untarnishable promise. The programme becomes treated as essentially good, and the negative experiences as excusable misfortunes.

Des Gasper, Institute of Social Studies, PO Box 29776, 2502 LT The Hague, The Netherlands (e-mail: gasper@iss.nl). 
The same syndrome of oscillation and untarnishability occurs commonly with other topics in development discourse like 'decentralisation', 'participation', or 'co-operation'. A policy means or approach is deemed inherently effective and desirable, although its good qualities may, it is said, often be disguised by other factors for which it is 'not to blame'. The means or approach has virtues but not failings. We can call this the 'beyond criticism' gambit.

Consider one example. Duelfer, amongst others, felt he must deny that service cooperatives have any inherent weaknesses.

The failures of cooperatives in some instances are often attributed to a 'structural weakness' of the cooperative society as compared with other organizational forms. Detailed study of these cases shows however that failure was in every instance conditioned by a lack of preparation, planning and 'take-off' in the newly created cooperative [Duelfer, 1974: 164] (emphasis added).'

The failings are always merely contingent, never structural. Yet Duelfer does not exclude notions of structural weaknesses elsewhere. He vigorously alleges them for collective farming and holds that service co-operatives have structural strengths, in that they allow fulfilment of some (purported) social prerequisites for economic development [ibid.: 189]. Having structural strengths and no structural weaknesses, service cooperatives are deemed essentially appropriate policy means.

I hope to counter these and some related oversimplifications in and about development (policy) discourse(s). This study focuses critically on a number of types of essentialism, including claims that a widely used term referring to a complex general category means ('essentially') exclusively such-and-such, and claims that a policy means or strategy is inherently (or 'basically') appropriate, desirable or 'proper'.

'Development discourse' (DD) as a field has no clear boundaries, since development and development studies have none either; further, the types of discourse in them are not all of one type. Since we face not one type of nail, no single type of hammer will suffice. Here are some alternative delineations of $\mathrm{DD}$, beginning with the broadest: (i) discourse that centrally uses the term (social/economic/political) development; (ii) discourse in development studies; (iii) discourse that uses 'developmentalist' presumptions (discussed in Sachs [1992]); (iv) discourse of development policy (see Apthorpe [1986]); (v) discourse of leading international development donors (see Ferguson [1990], Porter [1995]). ${ }^{2}$ We are interested in all of these, but especially the last three, which are somewhat more coherent. They overlap and have much in common; where necessary we will distinguish them.

From the descriptive/evaluative ambiguity of the term 'development' and its acquisition of a status beyond criticism, we sense DD's interconnections 
and overlaps with policy discourse. My prime interest here is development policy discourse; but like any policy discourse it is not sharply distinct from descriptive and explanatory discourse in the same subject areas [Stretton, 1969]. Development discourse (or discourses; we will return to this point later) is perhaps especially intimately related to policy, given too some of its common roles: to mobilise, to reassure, and to manipulate, through concealment of divisive issues. Indeed some authors treat DD as a policy discourse, by using develop as a transitive verb: A develops B. None of these roles though, nor the corresponding discursive manoeuvres such as positivenormative ambiguities or overlaps, is unique to DD. Much policy discourse shares what Ferguson proposes as characteristic of DD: the attempt to depoliticise, to present disputed matters which affect people differently and on which they have different perspectives as being technical issues with technical solutions including, not least, solutions of the sorts which the purveyor of the discourse is able to provide [Fischer, 1990]. Further, not all development policy discourse, let alone all policy discourse, has this feature. We have to study many patterns, not a few.

In section II we look at essentialism in defining terms, and William Connolly's work on the functioning of 'essentially contestable concepts' in political discourse. Section III proceeds to essentialism in representations of the performance and desirability of policies and policy means, including two linked dangers: performative essentialism, the treatment of a policy-means as having 'inherent' performance attributes, particularly inherent strengths or weaknesses; and prescriptive essentialism, the treatment of a means as being inherently appropriate or inappropriate. It takes a set of development policy illustrations: rural centres, agricultural co-operatives, and collectivisation. Section IV considers essentialism in descriptions of schools of development thought and practice, with reference to the work of Gavin Kitching, more recent writings by James Ferguson and others explicitly on 'development discourse', and the stream of 'anti-development discourse'. Section V sums up.

\section{ESSENTIALISM AND THE TERMS OF POLITICAL DISCOURSE}

One often encounters the defence that indicated examples of failure of a policy were not 'real' or 'true' exemplars of the approach. This 'not one of ours' gambit can be valid, but it is a warning light: investigate-with-care. In the absence of awareness of the imperfection of terms and the pitfalls associated with performative concepts, much confusion can arise. We must look first at essentialism in defining any single concept; in Section III we can then go on to forms of essentialism in broader policy discourses.

Essentialism in definition holds that there are precise and obligatory 
definitions. ${ }^{3}$ In a strong variant it holds that one can attain the ideal definition: a set of necessary conditions which together are a sufficient condition for use of a term [Scriven, 1970]. In practice we find we cannot do this, except for some new or rarely used terms, particularly those in specialised fields. ${ }^{4}$ This inability reflects the fact that we cannot envisage all possible conditions in which terms are or will be used. Usually we can state some necessary conditions, plus other 'criteria' which individually are not necessary but of which one or other sufficient combination is necessary. The set of such sufficient combinations is unlikely to be completely definable. 'Criteria' fade off into 'connotations', properties which happen to often occur in practice; there is no hard dividing line between the two. Connotations carry important information and it is unreasonable to try to excise them. And that is all there is: not any 'buried secret formula which encapsulates the meaning in a more precise way' [ibid.: 130]. Much of our perception and application of categories is through reference to concrete examples and unstated and incomplete patterns that are imputed from them. A range of imputations are possible, not just one; and they further evolve in use and as new examples arise. The evolution is aided by their remaining partly implicit.

Attempts to enforce ideally precise definitions will rapidly fail, because they can neither capture present-day nuances nor anticipate all future demands. A new term in a specialist field can be free of connotations, and so it has a temporary apparent perfection of definition. But, once it is put to use, it soon 'develops a life of its own', even in mathematics [ibid.: 131]. The history of its applications colours the inevitable gaps left by its defining conditions and criteria, and in effect modifies them.

This incompleteness of definition is also called 'open texture'. ${ }^{5}$ Incomplete definitions still have important content, for they exclude many things; this is the contrast theory of meaning [Scriven, 1976]. ${ }^{6}$ We instead refine a definition only as far as is required to establish a relevant difference in a particular usesituation. Openness is of course a matter of degree, and is usually greater for generalised and abstracted theoretical concepts.

One can illustrate these points for many a focus of discussion: 'ownership', 'socialism', 'class', 'equality', 'co-operatives', 'development', and so on. Commonly such terms span multi-dimensional activities or entities, for which general labels will be 'loose concepts' [Kamarck, 1983], that is, implicitly weighted indexes which aggregate and simplify and are unlikely to support strong behavioural generalisations. For example production systems usually involve numerous activities and inputs, for each of which the ownership, management and operation may then each in turn be private or collective (of various types); we thus need more than the two aggregate categories 'private' and 'collective'.? Connolly [1993] speaks similarly of 'cluster concepts'. The notion figures crucially in his theory of political discourse, which we will look at in a moment. 
In administration and law, ordinary terms are given more restricted meanings in order to reduce their openness of definition [Brennan, 1977: 96f]]. In contrast, proverbs in unrestricted everyday language, and many political declarations, trade on the gnomic force of brevity. For short statements can be read with whatever contextual conditions, refinements or qualifications one likes or finds convenient. Precision of language should not, however, be judged according to an unattainable perfection, but by reference to what is needed in a particular context. Ability to make such judgements is the mark of expertise in a situation. Proverbs are often on the surface mutually contradictory, but this need not make them false or vacuous. It is worth saying both 'look before you leap' and 'he who hesitates is lost', if there are not too infrequent circumstances where there is real danger of leaping too soon, and others with real danger of hesitating too long. Proverbs can thus have value as pitfall markers. They can have negative value if treated as laws; for example, the adages seen in traditional theories of planning and administration 'Coordinate! Collect information! Clearly specify objectives!' and so on which have been systematically criticised by Simon [1970] and Caiden and Wildavsky [1980].

Following Gallie [1956], Connolly holds that many central political terms, such as 'interests', 'freedom', or 'politics' itself, are 'essentially contestable'. Conflicting interpretations of them exist which reflect differences on many matters, which (probably) cannot fully be rationally resolved in practice and for the foreseeable future. Contributory elements include the following. (i) The terms concern cluster concepts whose various criteria are numerous and partly in dispute. (ii) These criteria use other concepts of which some are themselves essentially contestable; for example, many definitions of 'freedom' use the concept of 'constraint' [Connolly, 1993: 160]; definitions of 'development' may refer to 'opportunities', 'needs', 'autonomy' and so on. (iii) The disputes on meaning reflect not only factual and theoretical differences that are in principle resolvable one day, but also less tractable matters such as the conception of human agents. Thus the contestability of the concepts reflects the disputability of many basic political issues. Debate over the concepts is part of politics and is, in part, political [ibid.: 39-40].

Connolly suggests these central political terms are typically also partly descriptive and partly evaluative in character; or, better put (given that all descriptions are from some viewpoint), many of them describe from a moral viewpoint [1993: 39, 222ff]. Their evaluative content cannot be excluded: there is no necessary-and-sufficient set of neutrally descriptive criteria to determine correct use, because evaluation is part of the very point of such a concept (for example, the concept of freedom, or of what is in an agent's 'interest'). Without the evaluative point or purpose of the concept, one could not say which neutrally descriptive criteria were relevant, nor apply it sensibly 
in new cases. These cases have typically unique features and may raise issues that the concept's definition does not cover, and which therefore require intelligent judgement in light of the evaluative purpose of the concept. However, the nature and implications of the evaluative content are themselves partly in dispute. The concepts are thus truly essentially contested.

'Development' of societies is an essentially contested cluster concept, employing a metaphor derived from biology in particular. In attempting judgements about overall change or overall improvement, not of single organisms but of organisations or entire societies, the problem of subsuming multiple competing trends typically becomes severe. Compared to biology or child development or kindred fields, in development studies any obfuscation of descriptive and evaluative usages of 'development' is more problematic, for the very values involved in judgements of improvement are disputed more, not just their relative weights.

Connolly has given us an account of political concepts which presents simultaneously the scope and limits to political discourse. The theory is not about limits only, and cannot be read as justifying one in whatever political conclusion one likes. It asserts partial not unlimited contestability (otherwise, why would the theory itself have weight?), and not a Foucauldian conclusion of the primacy of power [Connolly, 1993: Ch.6]. For understanding essentially contested political concepts in full-blooded daily use, Connolly advises that we cannot satisfactorily divide them into descriptive and evaluative versions. To do so would miss the point of how people actually conceive and use these notions. But it does not mean that distinguishing descriptive and evaluative versions cannot help in clarifying ideas about major terms in policy discourse - such as 'development', 'needs', 'entitlements', 'decentralisation', and more ${ }^{8}$ - and in identifying some pitfalls and confusions in argumentation, as we see in the following section.

\section{ESSENTIALISM IN TALKING ABOUT POLICY-MEANS AND POLICY-ENDS}

\section{Performative Essentialism}

Commonly and naturally enough, some of a concept's conditions, criteria or connotations can be behavioural/performance features. Some concepts are behavioural (for example, 'an energetic man'). Yet behaviour is much more contingent than are, say, material attributes (for example, a person's eye colour). When talking of policy-means we especially wish to avoid performance features in their definitions, as these could become prejudgments of actual performance. Yet they may seem a normal part of everyday language; for example, if a co-operative is not functioning co-operatively, it feels natural 
to call it 'not a real co-operative', and to view co-operative functioning as part of the core of the term 'co-operative'. But 'co-operatives' would then be defined in such a way that 'co-operatives function co-operatively' holds for all cases, not merely most or some. 'Real' decentralisation of government is similarly supposed to necessarily advance popular participation. An asserted attribute is felt to be an empirical truth and yet is placed beyond empirical test."

A corollary of this is that different groups may assert different behavioural attributes, linked to different definitions. For example, Schumpeter claimed as 'an historical observation [what] to his critics ... seems a childish trick of definition' [Stretton, 1969: 120], namely that capitalism tended to generate liberty and peace. In contrast 'Lenin was the first to discover that capitalism "inevitably" caused war' [A.J.P. Taylor, 1963]. ${ }^{10}$ One can similarly note the welter of views on humans' essential nature.

Since behaviour is contingent on many things, it becomes important which contingencies are taken as the universe of observation when making claims of essential or general character. For pet policy-means, favoured tame settings are usually taken. It is then argued that undesirable effects are not inherent in the approach, but are only seen in 'distorting' settings; although if we took the range of actual settings these might suggest that some undesirable effects are presently inevitable. Persuasive descriptions emphasise as 'essential' those potentials of favoured systems which are liked, but for non-favoured systems emphasise those potentials which are disliked. Non-favoured systems get considered in wild settings, or at least in actual settings; here their essence is held to be revealed, unlike that of a pet system (for example, structural adjustment) which is held to be concealed by distorting factors.

Differing views on the impacts of official foreign aid may in the same way reflect views on its settings, specifically views on whether the (recipient) state is essentially promotional or essentially parasitic. For example, Peter Bauer repeatedly attacked the very term 'aid', which 'prejudges the results [and ensures] that there is an automatic case for further and increased aid'. He complained that examples of damage caused by 'aid' are dismissed by reference to the corrections and 'reforms which are always promised' [Bauer and Yamey, 1981: 2]. The irony is that Bauer himself shied away from systematic survey of effects, preferring the safe haven of an a priori logic of negative impact: (i) specific results are held to be untraceable because of 'shunting', that is, aid in effect releases domestic resources for purposes other than the donors intended and which cannot be known for sure; but what can be known is (ii) that it channels resources through governments, which are (supposedly) inherently indolent and pernicious as resource-mobilisers and spenders, and 'so' (iii) aid must be deemed pernicious itself.

The tame/wild settings chosen for analysis may even be purely artificial, as in much economic theorising. Since there is an immense range of choice 
amongst specifications of variables and assumptions, the temptation arises to use those which seem to show the strength of liked systems or weakness of disliked systems, and to call on observations only when convenient to back pre-formed conclusions. Other systems' actual performance is often compared with a preferred system's abstract charms; and the preferred system's actual performance is then assessed only after the other systems have been ruled out on grounds of their a priori 'inherent' defects or their actual imperfect performance.

\section{'Inherent Virtues'}

Positive (or negative) valuations can be incorporated into the intuited or declared essence of a policy-means. The valuations tend to be strong: no half measures. Belief in an essential virtuousness may, non-coincidentally, be combined with belief in essential definitions; both stances give reassurance.

It is in order that some concepts are valuative, and that independent/ intrinsic value is attached to particular things. For example, a major but finite value may be placed on freedom of the press in its own right, that is, regardless of its effects; and a limited - even if great - instrumental value may also be attached to it insofar as the freedom helps bring good products. If we go further than that, prescriptive questions become settled in advance of any evidence. " Problems arise when valuations are introduced without clarity and limit, and in the conceptualisation of a policy-means. Proclamations of overriding value figure in attempts to gain not just reassurance but also resources and privileges.

Sometimes policy-means are given an extreme positive valuation because the goals they represent are felt to be so good or even felt as objectively binding; but sometimes because they are felt to be so effective in advancing accepted goals. This last case, of instrumental worth, will be considered further here.

The notions of 'inherent strengths' and 'inherent weaknesses' combine these performative and valuative essentialisms: entities are held to have inherent behavioural features which are also valued as good or bad. We saw this earlier, in Duelfer's defence of service co-operatives and Bauer's attack on aid-recipient governments. Comparable points arise in assessing planning techniques. Complicated systems of cost-benefit analysis, for example, have various impacts, many of them good, but also some biases towards persons and sectors more suited for manipulation of the categories and procedures involved [Gasper, 1987]. Such biases could, in theory, be countered by case-by-case adjustments and supervision. Thus Alan Williams [1972: 529] claims that biases are 'not inherent in the method of analysis, but only in the way in which it may be used by some practitioners'. This underplays the scarcity of resources for planning and supervision; thus there are inevitable biases given the constraints that are everywhere current and will long remain in force. I do 
not argue that cost-benefit is 'on balance' inherently bad; only that it inevitably has some bad effects, and that, contrary to Williams, it is not inherently and thus always desirable. ${ }^{12}$

If one is to use the language of inherent features one must accept both structural weaknesses and structural strengths, that stem from an approach's particularities. Any feature could be the source of both. Better still would be to see all strengths and weaknesses as conditional: they are manifested in certain circumstances but not others. A feature may on balance be a strength in some circumstances but a weakness in others. Contrary to Duelfer, this conditionality does not imply that failings which are in principle counteractable are not real failings and that they cannot affect the overall ranking of the policy-means. How strong the effect is depends on the likelihood and cost of fulfilling the conditions for achieving strengths while avoiding weaknesses. Overall rankings should reflect these patterns of conditional appropriateness, not an alleged inherent general appropriateness or inappropriateness.

\section{Prescriptive Essentialism; Rural Centres, Cooperatives, and Collectivisation}

'Prescriptive essentialism' means to hold that a policy measure is inherently appropriate. I have already implied how common this is, given the fairly natural inclusion of valuative and performance features into concepts, and given also organisations' and professions' needs for self-belief. A weaker variant involves the presumption of appropriateness in broad but unspecified 'normal' circumstances; arguments on those lines are sometimes acceptable, as not too untrue. ${ }^{13}$ But something is clearly wrong when policies with very high requirements are considered as in no way inappropriate or flawed, but merely as let down by contingent weaknesses, which somehow exist in an inferior and separate realm from that of the virtuous policy concept.

Illustration 1 - Rondinelli on policies to promote urban centres for agricultural development

The disappointing results in Kenya and Panama were due largely to problems of implementation and insufficient political commitment to the strategies, rather than to the soundness of the concepts underlying them [Rondinelli, 1986: 243].

In Kenya:

[e]ven critics recognize that the shortcomings of the strategy lie primarily in implementation rather than in the appropriateness of the policies' ... [such a strategy] will require stronger political commitment, new and more serious efforts to coordinate the work of the dozen or more major ministries and agencies responsible for various aspects of the 
programme and expanded administrative capacity at the local level ... [etc. etc.] [ibid.:244, 245-6] (emphasis added).

And concerning those implementation problems:

As in Kenya, [in Panama] the problems of implementation arose not so much from the concept underlying this approach to regional development as from the complexity of the projects and the inability or unwillingness of national ministries and agencies to coordinate their activities [ibid: 250] (emphasis added).

This is not a manufactured example in a Schafferian text to illustrate excuses and 'escape-hatches' in policy evaluation. It is from an article by the perhaps most published and most influential regional development planning author of the 1970s and 80s. Extremer forms of defensive dissociation from problems experienced are found in the annals of state socialism.

Illustration 2 - Sharing the credit and shifting the blame in collectivisation campaigns

The thoughts of the Chairman are always correct. If we encounter any problem, any difficulty, it is because we have not followed the instructions of the Chairman closely enough (Lin Biao, cited in Wilson [1995]).

One important policy pattern is the unforeseen avalanche, illustrated by collectivisation/communisation/villagisation in the USSR in 1930, China in $1955 / 56$ and 1958, and Tanzania in 1974/75. Programmes originally envisaged to take years raced ahead to fulfil most of their targets within months, that is, in a time span leaving no possibility of serious evaluation and feedback. Apologists rightly note the role of local initiatives here, but not their context. The vanguard centre does not and cannot know exactly what is the situation and what is possible in each locality, but it has some broad picture and wants to lean in a particular direction at a particular time. So it holds up selected examples for emulation and tells local cadres and officials: 'Don't fear to press ahead with policy $X$ '. At the same time it covers itself by also saying 'Follow the mass line'. While the vagueness in instructions is partly unavoidable - for decisions must be made on the spot - it conveniently allows the centre to criticise cadres after they have acted, for having 'misinterpreted' instructions and lapsed into 'commandism' or 'tailism' (whichever suits the centre's convenience). Alternatively, the local cadres will be left sharing the credit for any success, and in second place to the farseeing centre, for they 'only' correctly interpreted its wise instructions [Frank, 1958/59].

The centre pays a price too. Local cadres do not know how valid are the 
centre's examples. Nor may the centre itself, but it needs to have some. Even if the examples are completely true, little may be known about how generalisable they are. Jack Gray [1974] was careful for these reasons to call the internally brandished Chinese examples 'myths'. Local cadres no doubt still give some credence to what the centre tells them is possible. They also wish to perform and not be open to the accusations of 'tailism' which others could use against them at this stage of the policy cycle (that is, prior to feedback from experience). The centre can start receiving reports from areas where conditions have proved easier for pressing ahead, plus some optimistically slanted reports; overgeneralise from them; decide it has underestimated mass enthusiasm, and redouble its pressure. Excesses and problems are later held to have 'resulted not so much from senseless directives from bureaucrats at the centre but rather from over-enthusiastic local cadres, many of whom took the prevailing rhetoric ... too literally', that is, literally [Sklair, 1979: 324]. The policy is still held to be essentially correct, when divorced from its 'contingent excesses' [ibid.: 313].

Belief in the inherent suitability of a policy-means can thus endanger the conduct of assessments in nearly all stages. In framing the assessment there is a tendency to neglect possible alternatives. In specifying objectives there are dangers of the favoured means coming to dominate more general ends, through endorsement of its specific form and traditions. In identifying performance, failures may be disowned (as not involving 'real' cases) and successes adopted, by switching between definitions (as in some defences of economic liberalisation); and successes may be unduly brandished, since success is assumed to be the representative case, found whenever the means is 'given a fair chance'. Next, in explaining performance, including failures, there is selective attention to seeking mitigation for the favoured approach, not for others; and (as we saw in the collectivisation and regional centres cases) a transfer of blame and responsibility to other forces and alleged misfortune. In sum, the danger is of self-reinforcing prejudgements, with criteria applied and evidence selected and interpreted in ways which endorse the initial stance. Such apologetics appear for many a problematic or controversial policy. Our third illustration shows most of these features.

\section{Illustration 3-Evaluation of Rural Co-operatives}

The absence of the conditions necessary for successful cooperatives was erroneously identified with failures of the cooperatives themselves [International Cooperative Alliance, quoted in (UNRISD [1975]).

In an earlier study Apthorpe and I noted the following features of a large body of co-operativist literature: (i) persistent neglect of important alternatives to co-operatives; (ii) a permissive extension of the definition of co-operatives, to 
include certain alternatives when those were successful; (iii) in contrast, a rigorous exclusion of many officially-established and recognised cooperatives that failed, as not being 'real' cooperatives, the definition of which in practice leans towards exclusion of the possibility of failure; or, whose failure is never their fault, but instead (iv) the fault of absent 'prerequisites' for success; leading to ( $\mathrm{v}$ ) a policy recommendation of 'fulfil the missing prerequisites' [Apthorpe and Gasper, 1979; 1982]. To claim that the 'prerequisites' for success were not provided, and that this is no fault of the policy, is one classic overall excuse. The worthy essence of co-operatives thus survives unscathedbut only through an implicit admission of limited powers and relevance, which stands in contrast to talk of inherent strengths and the claims to credit in those cases where the prerequisites were present.

The essentialist style in prescription is thus to call not just for the virtuous policy-means but for provision of its prerequisites for success, with little reference to cost and opportunity-cost. The World Bank [1981: 131-2] warns of the syndrome of arguing that 'the policy was good, only its management was bad; so we must provide more and better management' as if management was a non-scarce resource. Yet it argues in similar ways itself regarding structural adjustment.

In one way we can be indulgent; excuses ('anyone can make a mistake') and giving and taking credit are socially and psychologically required. Institutions and people seek to survive and go on. This does not remove the need in some instances to make summative assessments and choices. Policies cannot be judged primarily by their good intentions or supposed inherent worthiness regardless of actual performance. Problems arise when 'fideistic' motives become central, with needs for meaning being heavily expressed through attachments to particular policy-means. Criticism becomes perceived as impugning the essential worthiness of the policy-means and triggers acrossthe-board defence. There is even danger of disappointments intensifying the attachment, as past sacrifices cry out to be vindicated.

\section{ESSENTIALISM IN TALKING ABOUT DEVELOPMENT DISCOURSE}

\section{Essentialism in Labelling: Kitching on Populism and Neo-Populism}

We have looked at essentialism in definition and in discourses about policymeans. In this section we extend our attention to representations of whole theoretical and policy positions and even of development discourse in general.

When criticising a particular real discourse a central problem is that the positions to be analysed are themselves not perfectly defined. They are frequently vague, complex and marked by internal tensions. One part seems to say one thing, and another part to say something different. 
The tricky thing about reconstructions of any theory cum methodology is that they are unavoidably artificial. The aim is to show and to clarify the basic essentials of a particular view, but this can only be done by abstracting from the many particulars, in the fact the richness of that view. [So] [i]n a way, [Henry Bernstein and Howard Nicholas's] reconstruction of [Gunder] Frank's work is a caricature, but that amounts to saying that ice is cold [Coppens, 1984: 301].

The broader the position being characterised - for example, a 'paradigm' or 'orthodoxy' - the greater the difficulties. Some reconstructions are acceptable simplifications; others are unacceptable, such as assertions about the "basic essentials' of other views which implicitly refer only to 'the bits convenient to my argument' or 'the parts that I have not ignored'. How could Dudley Seers [1983: 42] conclude that '[t]he 21 st century visions of Herman Kahn and those of the Soviet futurologists are in essence the same'?

Several reviewers identify Peter Bauer as a mis-'labeller' in development economics [Thirlwall, 1985; Riddell, 1985], even after making allowances for the problems when attempting his type of broad critique. An arguable position suffers from excess. Similar points apply to Gavin Kitching's [1989] discussion of populism in development studies, in his widely-used and in many ways admirable textbook Development and Underdevelopment in Historical Perspective. ${ }^{14}$

Kitching claims that one mainstream in development studies shares a certain 'essential populist' vision of development [1989: 179] (emphasis added). Thus: 'None the less, even when all [the] discontinuities have been recognized ... the essential populist "vision"', as discerned by him in various thinkers from the 1810 s to the 1930 s, is still held by leading current developmentalists, including in the International Labour Office (ILO) [ibid:: 101] (emphasis added). Claims to know the 'essentials' of others' positions, better than they do themselves, ease his difficulties in fitting ILO, for example, into his neo-populist category. While 'in its recommendations on agriculture as on everything else, the ILO shows firmness about the general objective (maximizing productive employment) with a marked pragmatism about the means to be used' [1989: 73]; hey presto, 'despite all these differences we should note that the essential vision of development remains unchanged ... A world of small enterprise...of small towns and cities arranged in ordered hierarchy ... etc.' [1989: 83; emphasis added]. In reality ILO advocated more small enterprise, more emphasis on small towns and so on, than at present, within a mixed approach (walking-on-many-legs); but the invaluable word 'essential' - used similarly by Kitching at various points as we shall see - helps one to downgrade those parts of a position that are inconvenient for one's interpretation.

What concerns us here is the method of criticism, rather than whether 
Kitching's policy views are better or worse than those he attacks. In his usage the label of populism is a negative evaluation, given for example his judgement that contemporary 'neo-populism' does not work. A semi-pejorative label is then taken and applied according to convenience, with claims to know the 'essentials' of others' views, even if these contradict what the people referred to say themselves (a stratagem favoured also by Bauer).

The earlier thinkers whom Kitching discusses are presented as arguing that material progress 'can come about without large-scale industrialization and urbanization' [1989: 2], but instead by small-scale individual enterprise [1989: 19] and cooperative marketing. For inter-war 'neo-populism', the proposed 'essential features' [1989: 59; emphasis added] are different: now it was only held that 'large-scale industry ... must be supplemented by cooperative rural industrialization' [loc. cit.; emphasis added]. Elsewhere Kitching gives a cruder definition: that neo-populism 'opposes all forms of large-scale industrialization' [1989: 42]. Defining an easily demolished neo-populism allows Kitching to 'show' that China is not neo-populist, 'so' its areas of success do not in any way support arguments from writers whom he has stipulated as neo-populist.

Kitching claims that 'both populism and neo-populism share an overriding concern with problems of inequality in distribution' [1989: 99], a claim made also by Byres [Kitching, 1989: 92]. However, the examples that Kitching gives treat this concern as one to be balanced against others, not as overriding. The examples include Nyerere, who is quoted to that very effect [1989: 70] - but then disbelieved.

Selective belief is applied to Lipton too. 'I have presented Lipton as an antiindustrialist [sic]; though he goes out of his way to deny this' [Kitching, 1989: 90]. Similarly, 'Byres simply disbelieves the sincerity of Lipton's protestations'; and Kitching and Byres claim that neo-populist theories have 'vague time horizons' in which industrialisation is reserved for 'some distant future' [1989: 91]. It would be more accurate to suggest that Lipton was impressed by the patterns of dramatic industrial and national development on a small-farm basis that have been seen in East Asia, contrary to Kitching's suggestion that 'there is no historical or contemporary example of this combination' [1989: 136]. Lipton is one of several authors who argued for a particular sort of path to interdependent industrial-agricultural development.

Kitching repeatedly asserts that Tanzania after 1967 adopted a 'neopopulist' anti-industrialism. The claim is in tension with studies that indicated the presence of disincentive agricultural pricing and a strong weighting to industrial investment through the 1970s [Ellis, 1980; Bienefeld, 1982; ILO, 1982; Dolman et al., 1984]. Kitching also attacks neo-populist dissipation of resources across the whole country [1989: 121], although he notes elsewhere that 'a very conventional' concentration of much state agricultural investment was resumed from 1974 [1989: 118]. He concludes that: 'there is no doubt that 
overall results have been very disappointing' in Tanzania (p.108). The sources just cited note that economic and social results were in fact substantially better than the African average in the period to 1978 , in a country rather poorly placed at independence. ${ }^{15}$ It was on the basis of such results that in 1976-8 'decisions were ... taken, which either ignored foreign exchange implications, or considered them on the basis of absurdly favourable assumptions' [Bienefeld, 1982: 309], and stepped up import-intensive industrialisation plans while continuing the relative neglect of agricultural production and marketing. The warning from the balance-of-payments and food-supply crisis of 1973-5 was not taken, and Tanzania entered a major crisis initiated by external shocks from 1979.

This picture of an impetuous push for industrialisation is far from Kitching's. He defends his thesis of anti-industrialism by claiming that producer goods industries were neglected, and quotes Plan rhetoric of putting 'particular emphasis' on basic-needs related industries [1989: 123, 139]. One should note that these industries included even construction materials, and that few sectors will in practice fail to receive such epithets. The record of the several major 'basic' producer goods projects which were in fact started was very disappointing [Coulson, 1979; 1982]. While Kitching quotes Nyerere from 1965, calling for many small factories dispersed around the country rather than a single large factory [1989: 67], in industry after industry the studies of investment choices show the selection of the single large factory, often taken 'off-the-shelf' from a foreign supplier. So Kitching's criticism becomes 'not ... simply of an inadequate investment in industry but rather of investment in the wrong sort of industry and of the very inefficient manner in which all Tanzanian industries...are managed and operated' [1989: 122] - just the sort of ILO commentary he elsewhere labels neo-populist! ${ }^{16}$

Kitching tries to distinguish his position as follows. He claims that ILO and Lipton grasp only the importance of 'static efficiency' not 'dynamic efficiency'; and states of the latter: 'In its most developed form this idea is known as the 'Dobb-Sen' thesis on choice of techniques' [1989: 138]. That thesis [Sen, 1960] was superseded by more general formulations of investment choice (including by Sen; for example, UNIDO [1972]) that were drawn on by ILO (including through Sen's participation - for example, Sen [1975]) and others. These formulations do refer to possible future trends, as do market choices and East Asian strategies. The cases made by ILO, Lipton et al. clearly go beyond static efficiency.

Without Kitching's 'essential vision' one might not lump together Nyerere with Lipton and the ILO. Kitching's Chapter 4 quotes Nyerere from the 1960s, and summarises his view of Tanzania's future as 'essentially an agricultural one ... [with] a mass of self-reliant rural villages ... producing and consuming co-operatively, and dependent on agriculture at least for the foreseeable future' 
[1989: 66]; 'essentially rural and agricultural' [1989: 122; emphases added]. But in practice Nyerere - despite an alleged 'hostility to industrialization ... [which] strengthened over time [1989: 66] - also supported policies for state farms, large parastatals, including in industry, priority to industrial and infrastructural investment and so on; and this (inexplicitly) is the policy whose record is criticised in Kitching's Chapter 5. So Kitching's characterisation of Nyerere's intentions is outdated or too simple, and/or his assessment of 1970s' Tanzanian policy as having followed Nyerere's 1960s' intentions is wrong. He does later note that 'Nyerere has had ... considerable latitude to make state policy ... [but less to] have that policy implemented' [1989: 119]. For 'policy' one should instead read 'official statements of national ideals'. Nyerere also fails to fit in a populist slot which (as characterised on pages 137 and 175) excludes both an interest in collectivisation of agriculture and a stress on ownership of the means of production as a source of exploitation. ${ }^{17}$

I have queried Kitching's statements on essential features of populism and neo-populism, as too various and inconsistent; and his usage of the terms, including claims as to the essential features of certain authors' ideas, as again inconsistent, both internally and with other evidence. A wish to be emphatic motivates choice of essentialist language; but emphasis could be obtained in other ways and essentialistic usage leads to many difficulties. One does not have to be a defender of all policies of the post-independence elites in Tanzania and similar countries in order to query the swingeing, often somewhat lordly, yet partly inaccurate attacks by Northern fundis from both Left and Right (such as The Economist). These grandiose attacks have contributed to the present hostility of many in the African intelligentsia towards social scientists from the North.

Kitching wrote his book partly as a text for students. One has to attract their attention, locate issues historically, and make clear that there are contending positions. Can this justify 'cartoon' simplifications? - 'Development for Beginners'. One wants to trigger students to think logically, as well as empirically, creatively, realistically, fairly, broadly - and not just to be stimulated to have, or accept, views, or just stimulated. One can then feel uncomfortable with some 'paradigms in social science' textbooks, while accepting several of them as an advance on the traditional 'mainstream-only' variety. Presentation of contending views can be done without an overly manipulative authorial voice; Corbridge's [1993] 'Debt and Development' comes to mind. One can let other authors speak for themselves where possible, and follow a 'Maxim of Presumed Seriousness' [Klamer and McCloskey, 1989]. We must presume, until sound evidence contradicts it, that others are serious too, and have thought seriously. To disbelieve authors' own claims of where they stand on major issues may be a way of avoiding the labour of understanding their positions, and is also in the long run probably not effective in 'winning hearts and minds'. ${ }^{18}$ 


\section{Overgeneralisation on Development Discourse? Ferguson on Depoliticisation}

James Ferguson's incisive and influential The Anti-Politics Machine stipulates development discourse as something distinct from academic discourse on development [1990: 28]. Matching the focus of his doctoral research on a foreign-aided project in Lesotho, he treats development discourse as international agency/donor/adviser discourse [1990: 70-71]. The book floats some general theses on the basis of this single, somewhat extreme [1990: 73, 257 case. The theses deserve both attention and critique.

We should note first that many countries not dominated by aid still use development as a central term; by population these cover most of the South, plus perhaps the former Soviet bloc. And there are in most countries major influences on development discourses other than donors and their organisational convenience. Countries are not passive or discourse-less. If one believes, however, that the ideas, norms, blueprints and personnel determining 'development' come in large part from the North, notably from a few donor organisations, and even set most of whatever unity 'development' has, then one must indeed study those organisations as closely as possible (see the contributions by Gore and Moore in this collection; and Williams and Young [1994]).

One of Ferguson's theses concerns agency survival and growth. It holds that development discourse (DD) involves conceptualising recipient countries 'in such a way as to maximize the potential role of "development" agencies' [1990: 71]. Would this fit, for example, 1990s' agency and donor discourses in Eastern Europe? Ferguson states the thesis more broadly:

'development' discourse typically involves not only special terms, but a distinctive style of reasoning, implicitly (and perhaps unconsciously) reasoning backwards from the necessary conclusions - more 'development' projects are needed - to the premises required to generate those conclusions [Ferguson, 1990: 259].

Now, total foreign development aid declined substantially from some major donors in the 1980s, and project aid declined much more and for nearly all donors; the trends continue in the 1990s. This sharp relative decline of project aid does not disprove but raises questions about Ferguson's thesis.

The thesis implies that the forms of development discourse would vary country-by-country, in order to arrive from very different conditions to the above 'necessary conclusions'; for 'the South' is dramatically diverse. As a country-specific corollary, Ferguson posits four components of 'the' DD representation of Lesotho: (1) aboriginal; (2) agricultural; (3) a national economy; and (4) subject to governmentality. He does consider the last two to 
have universal relevance in DD: " ... "development" requires a bounded, coherent "national economy", responsive to the principle of "governmentality"" [1990: 257]. But like (1) and (2), (3) (a 'national economy') seems demonstrably non-universal, for example in donor discourses of the 1990s which can with open eyes consider Russia, Somalia, the Gaza strip or, indeed, Colombia. And (4) is formulated in such a way - 'the idea that societies, economies, and government bureaucracies respond in a more or less reflexive, straightforward way to policies and plans' [1990: 194] - as to be inapplicable in any country and unlikely to be assumed in many; not, for example, in Lesotho's' neighbours, South Africa and Mozambique. The development discourse that Ferguson identifies for Lesotho is far from universal.

Many projects fail in terms of their stated objectives while being more successful in terms of unstated agendas. Ferguson's second thesis is reminiscent of Bauer: development and aid promote bureaucratic state control, as distinct from development agency goals. He introduces it by criticising 'political economy' writers who leap beyond the evidence to assert that development activities are fully determined by economic or 'objective interests' [1990: 16]. Even if actors choose according to their 'interests', events may not further these, due to unforeseen factors and effects, including the agency of others. Ferguson arrives at a version in which development projects diverge from the intentions of planners and donors but in practice further the agendas of national elites who control the state. Projects are instrumental towards 'expanding the exercise of a particular sort of state power while simultaneously exerting a powerful de-politicizing effect' [1990: 21]; and 'technical "development" interventions [could be] ... systematically intelligible as part of a two-sided process of depoliticization and expansion of bureaucratic state control' [1990: 267]. But we can note that while aid programmes through a recipient State are likely to serve its purposes, aid agencies do not operate only through aid. Aid can be a lever to obtain broader influence over policies, so we can indeed find discourses from international donors which have furthered, not just espoused, reduction of the local State.

Since interests are perceived in large part through ideologies and beliefsystems which are discursively constructed then, as Escobar [1995: 210] puts it, there cannot be a materialist analysis that is not at the same time an analysis of discourses. Ferguson implies this in a chapter on 'The Bovine Mystique', when deconstructing technocrats' notions concerning why Basotho prefer to acquire cattle. ${ }^{19}$ While emphasising for Basotho cattle-owners both ideologies and interests and their interrelation, he seems independently to emphasise interests when discussing the spread of bureaucratic state power, and when deriving development agency ideology (the conceptualisation of Lesotho) from interests (agencies want more projects). Some other authors go deeper in the analysis of the interplay and tensions between interests and ideologies. ${ }^{20}$ 
Spanning and supporting the two theses mentioned is a third, concerning depoliticisation, stated at first for Lesotho but later posited world-wide [1990: 256. It holds that 'development' discourse represents the depoliticisation of poverty issues, whereby the above two effects (reproduction of development agencies and spread of bureaucratic state power) are effected through a conceptual apparatus which translates a reality of non-technical problems into 'simple, technical problems' for which the 'apolitical, technical, "development" intervention which "development" agencies are in the business of making' is then seen as appropriate [1990: 87]. This translation can involve both highlighting/ignoring selected aspects, and sheer inventing of problems 'solely for the purpose of being able to propose technical solutions to them' [1990: 88]. It hides 'extremely sensitive political operations' [1990: 250].

What Ferguson adds thus is a forceful extension of the theme of depoliticisation, stimulated by, as he says, a striking though extreme case. Some of his more specific claims or assumptions may be overdone or unsustainable if applied more widely: for example, that DD is non-academic donor-discourse (except if true by definition), presumes a national economy and governmentality, and is always structured around a veiled promotion of development agency activity and of bureaucratic state power. The book is marked by a tension between its single case and a tendency to hint about DD in general. On page 257 it first claims to have 'avoid[ed] making grand or general claims about the way the "development" apparatus functions in other settings' than Lesotho, yet also secondly that 'the exaggeration [his extreme case] produces, if properly interpreted, may be seen not simply as a distortion of the 'typical' case, but as a clarification ...'. The reasons offered - the standardisation and circulation of donor personnel and of donor thought/ideology - would apply at best only to donor-discourse. However, The Anti-Politics Machine seems to have filled a need within alternativedevelopment and anti-development discourses (see below), and the qualifying statements to its theses typically disappear when they are summarised elsewhere. ${ }^{21}$

If one is to have a single hammer for 'nailing' development discourse, then depoliticisation does quite well, up to a point. It fits the 'nails' of much donor discourse (as in Mitchell's [1995] devastating commentary on USAID) and considerable non-donor discourse too (see Tapscott [1995], on discussions within South Africa). But a description such as 'the technocratic depoliticized language of international development' [Crush, 1995a: xii] does not fit the language of political conditionality or human rights, or much of the discourse of many donors, notably numerous NGOs. Similarly Mitchell [1995: 149] asserts: 'Development is a discourse of rational planning'. Yet in some cases 'it' is instead more a discourse of national salvation, struggle and military-style campaign, in which costs are to be joyously borne rather than rationally 
weighed; sometimes a 'cargo-cult' discourse; and so on.

No single hammer can do the job. Better put, no single type of tool will suffice, for we do not face only nails. Consider three other contenders; they naturally partly overlap. Moore [1995: 7] offers another important focus: 'development discourse will be conceived as an integral part of capitalism's organizers' ongoing attempts to gain and maintain hegemony...all over the world'. Those attempts are not always through depoliticisation. And we must not overlook non-capitalist development discourses. Drinkwater [1991] outlines an equally plausible and equally limited claimant, this time of more Habermasian descent: a belief by policy makers and development agencies in their overwhelmingly superior knowledge, justifying their determination and imposition of policy. This better fits Stalinist or Maoist development discourse than does Ferguson's alternative. It also fits much other policy discourse (for example, Thatcherite); and it hardly fits progressive NGO or some Scandinavian donor discourse. Lastly, Kitching, Watts and others get good mileage out of the theme of populism in development discourse which we touched on earlier. Watts [1993: 267] speaks of attempts thereby to disguise differences and manufacture a national will; but populism can neither be equated to depoliticisation nor cover all of development discourse. ${ }^{22}$

\section{Reflections on 'The Development Discourse', Anti Development-Discourse and Anti-Development Discourses}

a new revelation from a prophet none other than the discourse of development itself [Escobar, 1995: 131].

I suggested at the outset that 'development discourse' (DD) as a field lacks clear boundaries, since development and development studies have none either, and further that the types of discourse in them are not all of one type. We can also see large overlaps not just between DDs and historical and contemporary political discourses, but in addition with administrative discourses [Hood and Jackson, 1994], bureaucratic discourse (a variant of the former), donative discourse (Schaffer, cited by Apthorpe [1986: 387-8]) and so on, each of which overlaps with the others. Ferguson's donor discourse unsurprisingly matches some other donative discourse, the discourse of institutional givers. Since there is so much that is non-distinctive in $\mathrm{DD}(\mathrm{s})$, attempts to define $i t /$ them by what is distinctive could become misleading.

For many authors a wish to specify 'the development discourse' or 'the discourse of development' in some singular fashion remains irresistible. ${ }^{23}$ They posit a fundamentally, essentially, unified practice and mind-set called 'development', expressed in 'the development discourse'. Authors who draw their approach for identifying this from theorists like Foucault or Schaffer (for example, Escobar, 1995: 41, 110] may find it hard to show that such discourse 
is distinctive, since those theorists claimed wider relevance. The claim, however, is that styles of group categorisation and labelling that are widespread in the modern world take on one special content in 'the' sphere of development.

Arturo Escobar claims to have identified 'the basic tenets of the development discourse', and 'the basic set of elements and relations that hold together the discourse ... the basic system of categories and relations' [Escobar, 1995: 151, 17] (emphasis added). Yet unlike Ferguson he does not limit himself to international donor discourse; his work has instead a strong Latin American emphasis. The content of the set of basic tenets, elements, categories and relations is not quite so clear but, for example, it must be emphasized that bureaucratic control is an essential component of the deployment of development' [ibid.: 145] (emphasis added). This 'development' seems then to exclude free-marketeers and important approaches prominent in the 1980s and 1990s. Elsewhere he assures us that: 'although the discourse has gone through a series of structural changes, the architecture of the discursive formation laid down in the period 1945-55 has remained unchanged' [1995: 42]. The tree model of intellectual systems here receives steelframe-language: surface switches such as between bureaucratic control and laisser-faire may conceal an unchanging underlying architecture. Porter [1995: 84] too sees just 'one modernist project' of development since 1945.

Without denying some of the profound continuities proposed by these and other authors, my concern is that they give to an ideal type of one part of development discourse (often a different ideal type per author) the status of a real description of the whole. Kitching was more modest, claiming only to discern one (populist) mainstream. From pieces rich in other insights, we take two examples of overgeneralisation. Moore [1995: 2] holds that: 'Equity, democracy and sustainability have emerged during the last fifty years as the core triad of ideological concepts within development discourse'. These terms do demand attention, and re-claiming; but are terms like growth, modernity, independence, liberation, autonomy, and security less 'core'? Next, for Manzo [1995: 237 ' $(t)$ he idea of the modern West as a model of achievement and the rest of the world as an inferior derivative, remains integral to the concept of "development". To whom? The Japanese, Chinese or Koreans? Iraqis and Iranians? To Robert Mugabe or Nelson Mandela or Julius Nyerere? Manzo herself talks of the quest for a counter-modernist 'development', no doubt stripped of this supposedly 'integral' feature. ${ }^{24}$

Categorising ' $a$ ' type of discourse - 'DD' or 'anti-development discourse' or whatever - has both potential virtues and dangers. The general danger is oversimplification and misrepresentation of complex discursive fields; for example, if one presumes that discourses which have one or some features in common (such as use of the concept 'development') will and even must have 
all major features in common. We have seen assertions about 'essential' elements of a discourse such that even if the 'essentials' are not avowed by an author, in fact clearly disavowed, they are still attributed to him/her by the commentator as a result of an assigned membership of that stream of discourse. Commentators can also homogenise through expanded use of key terms. In some writing on 'the development discourse', 'development' seems to become on occasion like the dancing Shiva, many but one, omnipresent: 'development can be seen as an apparatus', 'development as a form of story telling' [Crush, 1995b: 6, 14], 'Development proceeded by creating "abnormalities" ...', 'Development ... [employed] the premise of the Third World as inferior' [Escobar, 1995: 41, 54], and so on.

Moving beyond 'anti development-discourse', which seeks to characterise, explain, criticise, demolish and displace a DD, some writers enter 'antidevelopment' discourse [Watts, 1995: 45], A-DD. Practitioners of A-DD operate a reverse form of the 'beyond criticism' gambit. For them, 'development', in some partly elusive descriptive sense, seems to be presumptively and essentially bad. A-DD deserves attention as a genre in itself, with its own conventional foci and practices, patterns of mutual quoting and endorsement, and stylised 'facts', such as the oft-repeated and questionable claims that 'development', created in the 1940s, has impoverished most people in the South. Such examination requires another occasion. Some A-DD claims 'do not look too different from the totalizing and essentialist visions of the old sort' [Watts, 1995: 60].

Crush [1995b: 22] explicates the title of his book as follows: 'The power of development is the power to generalize, homogenize, objectify'. Trying to build counter-churches, as perhaps in A-DD, runs the danger of reproducing major features of Rome, such as overgeneralisation itself. Whilst Escobar gives an interesting discussion of cultural hybridisation globally, he seems not to acknowledge that hybridisation has happened to 'development' too. Yet as he notes on his penultimate page: 'If one were to look for an image that describes the production of development knowledge today, one would use not epistemological centers and peripheries but a decentralized network of nodes...' [Escobar, 1995: 225]. This diversity of development discourses concerns not only sites of production but also what is produced, how, about what, and to what end.

\section{CONCLUDING REMARKS}

I suggested that 'development discourse' includes various types of discourse; we have to study many patterns, not a few. A plurality of practices requires a plurality of concepts. A title of 'Essentialisms in and about development discourses' would thus have been more accurate, if perhaps overly fastidious. When should one emphasise diversity and when instead elements of unity, 
declaring a dominant trend and downgrading the rest as 'exceptions'? Taking essentialisms, overemphatic and often oversimplified conceptualisations, as the common theme here reflects a judgement that work on development policy and development discourse requires more concepts and more careful attention to concepts. The study proceeded with this in four stages: starting with common examples from various fields; next examining underlying difficulties with all concepts and with attempts at essential definitions; then examining a series of abuses in policy discourse; and finally assessing a set of recent descriptions of development discourse.

We began with examples: the frequent positive/normative ambiguity of the term 'development' itself; and the 'beyond criticism' and 'not one of ours' gambits. These and similar manoeuvres can sometimes be valid, but must be treated as warning signs, to be investigated critically. The terms 'basic', 'proper' and 'essentially' likewise all require a second look, and often a third and critical one. We paid particular attention later to assertions about the '(basic) essentials' of others' positions, which at times refer only to 'the bits convenient to my argument'.

In Section II we saw the problematic base of claims of essential content: concepts are not and cannot be totally defined (they have 'open texture'); and they evolve, which provides cover for tacit evolution of positions (see Gasper, in this collection). Many important concepts in social science and political discourse - 'development' no doubt included - are 'loose/cluster concepts'. Related to this, many concepts in political discourse are 'essentially contestable', because of disagreements over their boundaries and the weighting of different recognition criteria, and over the content of their evaluative and appraisive criteria.

Section III noted that some concepts incorporate valuative and performance claims. We saw how these understandable features of everyday language can become sources of pervasive confusion in policy argument, especially when socio-political identities are being sought and defended. Different groups often include different behavioural features in the definition of a policy means/ approach and make different tacit assumptions about settings. A purported essence containing both behavioural features and favourable valuations of them will have an alleged inherent desirability, whose unconditionality provides a focus for commitment. Such prescriptive essentialism - claims that a policy means is inherently appropriate - leads in turn to calls of 'fulfil the prerequisites for success', regardless of costs, alternatives, constraints. Deep problems arise when these fideistic motives become central in policy discourse; new learning is stifled, as we saw for example in cases of authoritarian agricultural collectivisation.

When describing intellectual positions, not single concepts, we face further problems, for the positions are often vague, complex, and inconsistent, 
especially so for whole schools of thought and practice (Section IV). We took three cases. First, we queried Kitching's statements on 'essential' features of populism and neo-populism in development studies; and criticised his usage of the terms, including claims as to the 'essential' features of certain authors' ideas. Second, we outlined Ferguson's forceful statement of tendencies to depoliticisation in development discourse, stimulated by a Lesotho case. We saw that some of his more specific claims or assumptions can be overdone or unsustainable if applied more widely. If one is to have a single theme for capturing development discourse, then depoliticisation does well up to a point; but it fails to fit language on, for example, political conditionality or human rights, or much of the discourse of many donors. No single theme can capture the territory, as we saw too for a few other contenders. Third, for various authors a wish to specify 'the development discourse' in a singular fashion remains irresistible. Without denying some of the profound continuities they suggest, I argued that they give to an ideal type (often a different one per author) of one part of development discourse the status of a real description of the whole. While recent work on 'development discourse' has been stimulating, often fruitful, sometimes even revelatory, it would benefit from less concern to find a single stylish hammer that will deal with development discourse in just one blow.

\section{NOTES}

1. Duelfer's study was the main background document for the 1972 FAO Rome conference on cooperatives and development.

2. Thus for the 1950 s Porter equates 'development practitioners' and 'technical assistance experts' [1995: 75].

3. The Collins English Dictionary gives these meanings. (A) Essence: 1. the characteristic or intrinsic feature of a thing, which determines its identity; fundamental nature. 2 . the most distinctive element of a thing. 3. a perfect or complete form of something; for example, he was the essence of gentility. 4. [Phily.] The unchanging inward nature of something as opposed to its attributes and existence. 5. [Theol.] an immaterial or spiritual entity. (B) Essential: 1. vitally important, absolutely necessary. 2 . basic; fundamental. 3. completely realized; absolute; perfect; for example, essential beauty. [4-6. from biology and music]. 7. something fundamental or indispensable.

4. In Lacey's [1976] words, whereas nominalism at most asserts the existence of nominal essences complete stipulations of a term's meaning, as for the newly created term - essentialism asserts real essences, holding that only one of the possible stipulations is correct and reflects reality.

5. Brennan defines 'open texture' as the inability to state necessary and sufficient conditions for use [1977: 104]. The phrase was introduced by Waismann in the 1940s. 'It is not, he explained [for reasons similar to in the contrast theory of meaning] to be confused with vagueness, being rather the possibility of vagueness. It characterizes most though not all empirical concepts. Take any material object statement. [For the] terms which occur in it ... we cannot foresee completely all possible conditions in which they are used ...' [Pan, 1979: 238].

6. To deny perfection of definition is not to assert a universal sameness. That would be the 'no bald men fallacy': that if all agree that a man with $x$ hairs is not bald, then surely a man with $(x-1)$ hairs is also not bald; and so on, until 'surely' a bald man is not bald. Instead we operate with a 
meaningful if fuzzy contrast between baldness and non-baldness.

7. See Rae et al. [198I] on the many dimensions of equality; Apthorpe and Gasper [1982] on definitions of 'co-operatives'; Blecher [1985] on production systems; and Wiles [1977] on property. We must go beyond 'the Victorian and Marxist [and Nozickian] oversimplification that ownership is an unambiguous, all-embracing, absolute power to dispose of something'; it is 'on the contrary ... a bundle of particular rights' which may be dispersed between many persons and institutions [Wiles, 1977: 35].

8. On decentralisation see Ferguson [1990: 205, 225], Gasper [1991], Slater [1989] and a special section in Development and Change, July 1990; on entitlements see Gasper [1993a]; on needs see Gasper [1996].

9. This syndrome involves definition of means in such a way as to be beyond criticism. A related syndrome is to impute ends from the specified means. A third type is imputation of ends from outcomes. A fourth, weaker, prejudgement is imputation of ends from one's approach more generally. 'Empirical tests are not very relevant, anyway, because the objectives ... are derived from the theories', claimed the late Dudley Seers [1983: 33]; but one can still be assessed by those objectives. Besides such prejudgements there are other types of bias, for example, from particular techniques; and other types of failing besides bias, like random inaccuracies.

10. Taylor continued: '[Lenin] discovered this only when the First World War was already being fought. Of course he was right. Since every great state was capitalist in 1914, capitalism obviously "caused" the First World War - but just as obviously it had "caused" the previous generation of peace'. Stretton [1969] and Apthorpe and Gasper [1979] analyse Schumpeter's contortions to defend ('true') capitalism against claims of any undesirable behavioural tendencies. The latter article further analyses concepts of essentialism. See also the literature summarised in Booth [1993] that has criticised essentialistic analyses by some Marxists and neoMarxists of supposedly inexorable trends of capitalist systems, and their use of over-aggregated categories.

11. Consider the following. 'The censored press remains bad, even if it brings forth good products, for these products are good only insofar as they represent the free press within the censored press ... The free press remains good, even if it brings forth bad products, for these products are apostates from the character of the free press' (Marx, quoted by Kamenka [1962: 27]).

12. Williams partly defends cost-benefit analysis in terms of its good intentions rather than its practice. His adoption bid for Wildavskyian policy analysis thus claims it is just 'cost-benefit analysis writ large' [1972: 533]. Fromm [1957] and Schumacher [1977] comment on a possible narcissism in assessing oneself by different standards (one's good intentions, which may justify one's resort to any means) than one applies to most others (whom one judges by their actions). Enemies can even be judged by what one presumes are their bad intentions, and their good actions be seen as devilish deception.

13. Henderson [1985] resisted this when discussing essentialism in economic policy. For him, the variety of 'policy soap operatics' that he calls 'essentialism' is the presumption that some industries - 'clear to any experienced person' - are essential; these are typically 'basic' industries, for example, energy. While he is rightly sceptical of such a simple investment criterion, there is a serious though not overriding case for national autarchy in such industries, in an uncertain, often conflict-ridden, world.

14. The 1982 and 1989 editions are identical for the sections I discuss; the second edition adds a postscript. See Foster-Carter [1985] for another comment on the looseness of Kitching's use of 'populism'.

15. Kitching [1989: 189] argues that pre-1979 Tanzanian data exaggerate. Was this more than in other countries? And the main issue here is not how well 1970s' Tanzanian policies performed, but whether they were anti-industry; the answer is not.

16. See Kitching's Chapter 4 on ILO's 'sophisticated critique of large-scale capital-intensive industrialization as this has occurred ... in developing countries' [1989:82].

17. Kitching finds it 'significant that [Nyerere's 1960s'] discussion of nationalisation and of peasant co-operatives occurs in the context of distribution, not production' [1990: 70]. Tanzania in the 60 s had little manufacturing to speak of, but the existing agricultural estates were subjected to nationalisation and production co-operatives were officially promoted in a later phase.

18. Gavin Kitching has expounded his approach as follows (personal communication). Introductory 
textbooks must in the first place generate reader interest. Where possible they should do this by: having a clear narrative or plot line; treating different topics in relation to a unifying theme, such as the critique of 'populism'; and deliberately adopting a somewhat simplified and coloured manner of presenting arguments, with the novice student invited to choose between mutually exclusive alternatives, not to synthesise, and with the author's own views to the fore. Checking on the meaning of terms and their consistent usage, on the accuracy of the alternatives presented, and so on, can be left to a later stage of learning, after students have first become involved in the subject-matter by a vividly judgemental intellectual saga. The degree of precision appropriate in characterising intellectual positions depends on context and audience; so if some students have absorbed and been favourably impressed by a caricature version of Lipton, the author's task is to make an effective counter-attack, which given the level of the audience must itself inevitably remain somewhat of a caricature. I differ on a number of points, and perhaps also on what is the acceptable level of simplification. First, can one only involve students through an emphatically judgemental presentation? I suggest not. Second, one should comment on both the caricature of Lipton and his own views, and distinguish them; otherwise transactions become 'crossed'. Third, what does one primarily want students to learn? - an approved view, or a sensitivity to different views and to logic and evidence? I would stress the latter. Finally, is advocacy via major simplifications an effective long-term way of advancing a viewpoint, in contexts where people have access to counter-evidence and counter-presentations for other viewpoints? Again I would suggest not.

19. ' ... cultural rules structuring property can never be accounted for by appealing to individuals and their rationality (or their "values"), for individual choices only occur within and in terms of a cultural order which is invisible to utilitarian theory (cf. Sahlins 1976)' [Ferguson, 1990: 137].

20. Similar comments may apply to Moore [1995]. Like Ferguson he separates development agency discourse and academic development discourse, but (i) gives better labels (development agency discourse and academic development discourse respectively), rather than defining development discourse as agency discourse, and (ii) examines their interrelation. However, his diagrammatic model [ibid.: 12] excludes non-agency, non-academic, discourse; and presents academic discourse as mainly acted on by agency discourse, much more than vice versa, and not directly acted on by nor influencing social realities beyond the agencies.

21. For example, 'James Ferguson (1990) has shown that the construction in development literature of Third World societies as less developed countries - similar to the WB mission's construction of Colombia as underdeveloped in 1949 - is an essential feature of the development apparatus' [Escobar, 1995: 47], though Ferguson only examined Lesotho. Escobar also accepts the second thesis, on development projects' unforeseen 'instrument-effect' of 'governmentalizing social life' [1995: 146], and tries to repeat the analysis for Colombia, but with limited evidence.

22. I have sketched elsewhere a discursive field of 'development studies as a frequently moralizing generalizing policy discipline', including nine or ten loosely articulated tendencies, not a single fixed package [Gasper, 1993b: 5]; that picture too simplifies and is incomplete.

23. For a few examples of the use of these phrases, see Sachs [1992: 4]; Mitchell [1995: 150, 156]; Shrestha [1995: 266]; Escobar [1995: 12, 154-6, 213-4].

24. The corresponding definition of 'integral' is 'being an essential part (of); intrinsic (to)' [Collins Dictionary].

\section{REFERENCES}

Apthorpe, R., 1986, 'Development Policy Discourse', Public Administration and Development, Vol.6, No.4, pp.377-89.

Apthorpe, R. and D. Gasper, 1979, 'Public Policy, Meta-Evaluation and Essentialism', Occasional Paper No.75, Institute of Social Studies, The Hague.

Apthorpe, R. and D. Gasper, 1982, 'Policy Evaluation and Meta-Evaluation: The Case of Rural Cooperatives', World Development, Vol.10, No.8, pp.651-69.

Bauer, P. and B. Yamey, 1981, 'The Political Economy of Foreign Aid', Lloyds Bank Review, Oct., pp.1-14.

Bienefeld, M., 1982, 'Tanzania: Model or Anti-Model?', in M. Bienefeld and M. Godfrey (eds.), The 
Struggle for Development, Chichester: Wiley, pp.293-332.

Blecher, M., 1985, 'Inequality and Socialism in Rural China', World Development, Vol.13, No.1, pp.115-21.

Booth, D., 1993, 'Development Research: From Impasse to a New Agenda', in F. Schuurman (ed.), Beyond the Impasse - New Directions in Development Theory, London: Zed, pp.49-76.

Brennan, J.M., 1977, The Open Texture of Moral Concepts, London: Macmillan.

Caiden, N. and A. Wildavsky, 1980, Planning and Budgeting in Poor Countries, New Brunswick, NJ: Transaction Books.

Connolly, W.E., 1993, The Terms of Political Discourse, 3rd Edition, Oxford: Blackwell.

Coppens, H., 1984, 'Frank's Crisis', Development and Change, Vol.15, No.2, pp.301-18.

Corbridge, S., 1993, Debt and Development, Oxford: Blackwell.

Coulson, A., 1982, Tanzania: A Political Economy, Oxford: Oxford University Press.

Coulson, A. (ed.), 1979, African Socialism in Practice, Nottingham: Spokesman.

Crush, J., 1995a, 'Preface', in Crush (ed.) [1995: xi-xiv].

Crush, J., 1995b, 'Introduction: Imaging Development', in Crush (ed.) [1995: 1-23]

Crush, J. (ed.), 1995, Power of Development, London: Routledge.

Dolman, A. et al., 1984, Development Strategy and Transformation in Tanzania, The Hague: RIO Foundation.

Drinkwater, M., 1991, The State and Agrarian Change in Zimbabwe, London: Macmillan.

Duelfer, E., 1974, The Operational Efficiency of Agricultural Cooperatives, Rome: FAO.

Ellis, F., 1980, 'Agricultural Pricing Policy in Tanzania 1970-1979', Economic Research Bureau, University of Dar es Salaam.

Escobar, A., 1995, Encountering Development, Princeton, NJ: Princeton University Press.

Ferguson, J., 1990, The Anti-Politics Machine: 'Development', Depoliticization and Bureaucratic Power in Lesotho, Cambridge: Cambridge University Press.

Fischer, F., 1990, Technocracy and the Politics of Expertise, Newbury Park, CA: Sage.

Foster-Carter, A., 1985, Book review, Journal of Development Studies, Vol.21, No.2, pp.294-6.

Frank, A.G., 1958/59, 'Goal Ambiguity and Conflicting Standards', Human Organization, Vol.17, No.4, Winter.

Fromm, Erich, 1957, The Art Of Loving, London: Allen \& Unwin.

Gallie, W., 1956, 'Essentially Contested Concepts', Proceedings of the Aristotelian Society, Vol.56.

Gasper, D., 1987, 'Motivations and Manipulations: Some Practices of Project Appraisal and Evaluation', Manchester Papers on Development, Vol.3, No.1, pp.24-70.

Gasper, D., 1991, 'Decentralization of Planning and Administration in Zimbabwe - Intemational Perspectives and 1980s Experiences', in The Limits of Decentralization in Zimbabwe, Institute of Social Studies, The Hague, pp.7-50, and Working Paper No. 64, Institute of Social Studies, The Hague.

Gasper, D., 1993a, 'Entitlements Analysis - Relating Concepts and Contexts', Development and Change, Vol.24, No.4, pp.679-718.

Gasper, D., 1993b, 'Policy Analysis and Evaluation - An Agenda for Education and Research', Working Paper No.140, Institute of Social Studies, The Hague.

Gasper, D., 1996, 'Needs and Basic Needs', Working Paper No.210, Institute of Social Studies, The Hague, and forthcoming in G. Koehler et al. (eds.), Questioning Development, Marburg: Metropolis Verlag.

Gray, J., 1974, 'Mao's Strategy for the Collectivization of Chinese Agriculture', in E. de Kadt and G. Williams (eds.), Sociology and Development, London: Tavistock, pp.39-65.

Henderson, P.D., 1985, Innocence and Design, Oxford: Blackwell.

Hood, C. and M. Jackson, 1994, 'Keys for Locks in Administrative Argument', Administration and Society, Vol.25, No.4, pp.467-88.

ILO, 1982, Tanzania: Basic Needs in Danger, Geneva: International Labour Office.

Kamarck, A.M., 1983, Economics and the Real World, Oxford: Blackwell.

Kamenka, E., 1962, The Ethical Foundations of Marxism, London: Routledge \& Kegan Paul.

Kitching, G., 1989, Development and Underdevelopment in Historical Perspective, London: Routledge (2nd Edition); London: Methuen (1st Edition, 1982).

Klamer, A. and D. McCloskey, 1989, 'The Rhetoric of Disagreement', Rethinking Marxism, Vol.2, No.3, pp.140-61. 
Lacey, A. R., 1976, A Dictionary of Philosophy, London: Routledge \& Kegan Paul.

Manzo, K., 1995, 'Black Consciousness and the Quest for a Counter-Modernist Development', in Crush (ed.) [1995: 228-52].

Mitchell, T., 1995, 'The Object of Development - America's Egypt', in Crush (ed.) [1995: 129-57].

Moore, D., 1995, 'Development Discourse as Hegemony', in D. Moore and G. Schmitz (eds.), Debating Development Discourse, London: Macmillan, pp.1-53.

Pan, 1979, Pan Dictionary of Philosophy, London: Pan.

Porter, D., 1995, 'Scenes from Childhood - the homesickness of development discourses', in Crush (ed.) [1995: 63-86].

Rae, D. et al., 1981, Equalities, Cambridge, MA: Harvard University Press.

Riddell, R., 1985, 'Bauer on Aid', Development Policy Review, Vol.3, No.1, pp.103-8.

Rondinelli, D., 1986, 'The Urban Transition and Agricultural Development', Development and Change, Vol.17, No.2, pp.231-63.

Sachs, W. (ed.), 1992, The Development Dictionary, London: Zed.

Sahlins, M., 1976, Culture and Practical Reason, Chicago, IL: University of Chicago Press.

Schumacher, E., 1977, A Guide for the Perplexed, London: Sphere.

Scriven, M., 1976, Reasoning, New York: McGraw-Hill.

Seers, D., 1983, The Political Economy of Nationalism, Oxford: Oxford University Press.

Sen, A., 1960, Choice of Techniques, Oxford: Blackwell.

Sen, A., 1975, Employment, Technology and Development, Oxford: Oxford University Press.

Shrestha, N., 1995, 'Becoming a Development Category', in J. Crush (ed.), op.cit., pp.266-77.

Simon, H., 1976, Administrative Behaviour, 3rd edition, New York: Free Press.

Sklair, L., 1979, 'Relations of Production, Productive Forces and the Mass Line in the Formation of the Rural People's Communes in China', Journal of Peasant Siudies, Vol.6, No.3, pp.311-41.

Slater, D., 1989, 'Territorial Power and the Peripheral State: the Issue of Decentralization', Development and Change, Vol.21, No.3, pp.501-31.

Stretton, H., 1969, The Political Sciences, London: Routledge \& Kegan Paul.

Tapscott, C., 1995, 'Changing Discourses of Development in South Africa', in Crush (ed.) [1995: 176-9].

Taylor, A.J.P., 1963, The Origins of the Second World War, Harmondsworth: Penguin.

Thirlwall, A., 1985, Book review, Journal of Development Studies, pp.479-80.

UNIDO, 1972, Guidelines for Project Evaluation, prepared by P. Dasgupta, S. Marglin and A. Sen, Vienna: UNIDO.

UNRISD, 1975, Rural Institutions and Planned Change, Vol.VIII, Geneva: UN Research Institute for Social Development.

Watts, M., 1993, 'Development I: Power, Knowledge, Discursive Practice', Progress in Human Geography, Vol.17, No.2, pp.257-72.

Watts, M., 1995, "A New Deal in Emotions" - Theory and Practice and the Crisis of Development', in Crush (ed.) [1995: 63-86].

Wiles, P.J., 1977, Economic Institutions Compared, Oxford: Blackwell.

Williams, A., 1972, 'Cost-Benefit Analysis: Bastard Science and/or Insidious Poison in the Body Politick?', in R. Haveman and J. Margolis (eds.), Public Expenditure \& Policy Analysis, 2nd Edition, Chicago, lL: Rand McNally, 1977, pp.519-45.

Williams, D. and T. Young, 1994, 'Governance, the World Bank and Liberal Theory', Political Studies, Vol.42, pp.84-100.

Wilson, L., 1995, 'Mao's Pleasure', London Review of Books, 5 Oct., pp.15-16.

World Bank, 1981, Accelerated Development in Sub-Saharan Africa, Washington, DC: World Bank. 